\title{
Multi-aspect potential of project activities in the university (based on the innovative platform project material)
}

\author{
Olga Nikolaevna Chelyukanova ${ }^{1}$ and Natalia Evgenievna Titkova \\ Arzamas Branch of the Lobachevsky State University of Nizhny Novgorod, Department of Russian \\ Language and Literature, Arzamas, Russia
}

\begin{abstract}
The article discusses the methodology of work on the project of the "Revival of traditions of family reading in the modern spiritual education of children and youth" innovative platform, organized in the Arzamas branch of the SUNN. The project is a cumulative phenomenon that synthesizes the scientific and methodological experience of leading teachers, psychologists, and organizers of children's reading, research scientists of children's literature. The project involves scientists, teachers of educational institutions of different levels, students, children of different ages, and their parents in a wide joint creative activity. Particular attention in the development of this practice-oriented innovative project is paid to the activities of the student initiative group and its pedagogical effect. The educational strategy of the project contributes to the development of constructive critical thinking and is aimed at developing a wide range of professional competencies among students participating in the project: professional and pedagogical, communicative, general cultural, and informational. The article pays particular attention to the description of the complex of educational products and forms of methodological assistance to teachers and parents. In the process of implementing this project, the urgent needs of teachers and families participating in the project are met. Those include the acquisition of methodological experience in working with parents and children to popularize children's literature and family reading; practical experience of working with a children's book in a family circle; the acquisition of artistic reading and recitation skills by the project participants; the generalization and systematization of scientific and methodological experience in the field of children's literature and family reading; family and creative literary communication; the introduction to the literary study of local lore. Literary and ethical-artistic questions are brought to spectators through theatrical communication.

Keywords: innovative platform, innovative project, family reading, children's literature, professional competencies, educational strategies, pedagogical technologies
\end{abstract}

\footnotetext{
${ }^{1}$ Corresponding author: ecc.0708@mail.ru
} 


\section{Introduction}

Management of experimental sites [1] is one of the priority directions of activity of higher educational institutions of pedagogical orientation. Most often kindergartens act as such organizations. The criterion for the successful work of the site manager is the assignment of the innovative status to it [2].

Work on a project for an innovation platform is, as a rule, a collective process. It acquires completeness and significance with the participation of student initiative groups. The guarantee of effective pedagogical influence on the personality of the student - the future teacher - rests in the harmonious synthesis of scientific, methodological, creative activity.

A methodology for working on the "Reviving the traditions of family reading in the modern spiritual education of children and youth" innovative project organized in the Arzamas branch of the SUNN is proposed as an example of successful cooperation between a team of teachers and a group of students. The project is a cumulative phenomenon that synthesizes the scientific and methodological experience of leading psychologists, teachers, and organizers of children's reading, researchers of children's literature.

Currently, more and more teachers, educators, methodologists, scientists, cultural workers are involved in the process of reviving the traditions of family reading in our country [3]. Libraries [4], schools [5] are becoming centers of creative and educational activities in this direction. Joint activities of schools and libraries are being established [6].

The relevance of the project is explained by the fact that today the educational institutions of the city do not have sufficient methodological support for organizing family reading. Many families do not have a culture of reading, most parents do not possess the skills to familiarize children with reading, and are poorly oriented in children's literature. The main provisions of the project correlate with the state concept of the National Program for the Support of Children and Youth Reading in the Russian Federation, approved by the order of the Government of the Russian Federation dated June 3, 2017, No. 1155-r, and other main state documents in the field of strategic planning and innovative development of the country, culture, education, parenting, family policy. Attracting students to project activities is a significant component of the educational strategy.

Work in this direction is also relevant because it allows correcting to some extent the situation with the change in federal educational standards. The content of competencies has been changed in such a way that education is increasingly considered as a service, and not as a pedagogical process. This cannot but make it difficult for the "teaching staff to educate the young generation of teachers in the traditional paradigm of national education" [7].

The objectives of the project are:

1. Identification of "pressure points" in the cultural and educational space that impede the creation of such a family way of life, where books, reading, general cultural and educational leisure would be the norm, and the formation of an environment and forms of activity that contribute to familiarizing the family with the family reading tradition.

2. Raising the status of family reading, developing cultural and reading competence of parents, children, and adolescents, as well as organizing and conducting various kinds of activities that, based on reading experience, form high civic and spiritual guidelines for the younger generation.

3. Creation of a scientific and methodological basis for the development and support of family reading, contributing to the introduction to spiritual and moral values. 


\section{Results and discussion}

The participation of the student initiative group in the development of a practice-oriented innovative project contributes to the development of constructive critical thinking, the formation of key competencies of students in the pedagogical direction including professional-pedagogical, communicative, general cultural, and informational competencies. The project contains a set of various kinds of events that are held on the basis of an innovative platform.

The qualitative results of the project are associated with the introduction of the family to spiritual values through the revival of the traditions of family reading by increasing its status, reading activity and improving the quality of reading, by the development of cultural and reading competence of children, youth, and their parents. In addition, "communication with a good children's book integrates a whole range of leisure activities, such as play, creativity, self-education, entertainment, etc." [8].

The activities within the framework of this project stimulate the formation of high civic, spiritual, and moral guidelines among the younger generation, as well as ensure the creation of a scientific and methodological basis for the development and support of family reading. Family institution strengthens in the process of reading together and, as a result, the interests of all its members draw closer. The implementation of the project contributes to the purposeful work with parents of children and adolescents based on the principle of co-creation, which will ultimately contribute to improving the general culture of the family, its spiritual revival, raising the consciousness of parents to a new level of presenting the personally significant value of reading communication for both parents and children.

In the process of implementing this project, the urgent needs of teachers and families participating in the project are met. Those include the acquisition of methodological experience in working with parents and children to popularize children's literature and family reading; practical experience of working with a children's book in a family circle; the acquisition of artistic reading and recitation skills by the project participants; the generalization and systematization of scientific and methodological experience in the field of children's literature and family reading; family and creative literary communication; the introduction to the literary study of local lore.

The work within the framework of this project makes it possible to establish and streamline the work of educational institutions (kindergarten, school, university) with libraries. This makes it possible to outline ways to solve one of the urgent problems associated with the fact that currently, as the latest research shows, "public libraries are information and educational resources only to a small extent" [9].

As a result of the project, it is planned to create a complex of educational products and forms of methodological assistance:

1. The "Reading Family" spiritual and educational program for teachers and organizers of children's reading, with scientific and methodological comments in the Appendix. It is aimed at popularizing children's books and forming a culture of family reading in the modern educational space;

2. The script (a cycle of scripts in the long term) of the "Chasing the Blue Bird" theatrical intellectual show for the pupils of the kindergarten and gymnasium, as well as their parents;

3. The script of the cycle of educational programs "Is there anyone who doesn't know how, doesn't like, doesn't want to read?" on a local TV channel; 
4. The "Children's book in the circle of family reading" collective monograph, which reflects the results of joint scientific and practical work of scientists, teachers, organizers of children's reading in the framework of the International Forum;

5. An album of drawings of the "Books of our grandparents will never get old!" traveling exhibition of children's illustrations;

6. The cycle of scenarios of the "Literary path" theatrical excursions;

7. Guidance paper for parents on the organization of children's reading (based on the results of the work of "The Reading Hut" Family Literary Club) with the creation of a mini-library of children's books.

The educational strategy of the project is aimed at developing a wide range of professional competencies among the participating students.

A lecture course for parents and teachers of an Orthodox kindergarten on the benefits of family reading synthesizes the scientific and methodological experience of leading psychologists, teachers, and organizers of children's reading, scientists, and researchers of children's literature. Students' help in the development of lectures is an important condition for its generalization and appropriation.

The participation of student youth in the creation of a series of television programs ("Is there anyone who doesn't know how, doesn't like, doesn't want to read?") popularizing children's books contributes to their involvement in journalism, expands the horizons of their career guidance. Students try on the roles of TV presenters, editors, screenwriters, correspondents.

Work within the framework of the "Revival of Family Reading Traditions in Modern Spiritual Education of Children and Youth" International Scientific and Practical Forum is an invaluable experience of business communication and scientific interaction of students with leading scientists and educators, as well as specialists in the field of children's literature. Participation in the preparation of the "Family Reading in the Modern Educational Space" scientific and methodological seminar contributes to the systematization of the acquired knowledge and practical skills during the implementation of the project.

The organization of the "Literary Path" theatrical excursions to the literary and local history places of Arzamas enriches students with knowledge in the history of their native land, acquaints them with the specifics of museum and guide work. The focus on theatrical form develops acting skills as an important component of pedagogical activity.

Participation in the creation of a traveling exhibition of illustrations for favorite children's books ("Books of our grandparents will never get old!") directs students to consultative, creative, and methodological assistance to children and parents in understanding the synthesis of painting and literature.

The development of training sessions ("The Reading Hut") on familiarizing with reading and artistic reading for kindergarten pupils (with the participation of parents) requires students to improve their recitation and rhetoric skills, and the use of various psychological and pedagogical techniques. This kind of activity encourages students to study the classics of children's literature and keep track of novelties in the field of children's reading.

Participation in the theatrical intellectual show for children named "Chasing the Blue Bird" activates the cognitive interest of students in the study of Russian folklore and literary fairy tales. The theatrical form and its game component contribute to the formation of students' mastery of artistic influence on the audience, as well as the development of organizational skills. That is an important component of the professional image of the teacher and an integral criterion for the effectiveness of the pedagogical process. 
In addition, literary and ethical-artistic questions are brought to a wide audience through theatrical communication.

The theatrical intellectual show for children named "Chasing the Blue Bird" contributes to the development of the educational potential of preschoolers and the increase of their general cultural level. Through a quiz game, spectators and participants comprehend the laws of the fairy tale genre, trace the relationship between folk and literary fairy tales, and playfully create a fairy tale themselves [10]. It seems possible to create a cycle of this kind of game based on the genre principle (fable, adventure literature, fantasy, etc.) with the involvement of younger students.

\section{Conclusion}

Thus, already at the stage of development, an innovative project is a "system and network platform for organizing the developing space of innovative education, capable of quickly and effectively spreading corporate knowledge horizontally" [2].

The effectiveness of project activities [11] is ensured by the synthesis of modern pedagogical technologies and scientific knowledge [12]. The participation of the student initiative group in the development of a practice-oriented innovative project contributes to the development of constructive critical thinking, the formation of key professional-pedagogical, communicative, general cultural, and informational competencies of students in the pedagogical direction [13].

\section{References}

1. Y.V. Makarenko, Humanities, 3(35) (2016). Accessed on: April 27, 2021. [Online]. Available:

http://cyberleninka.ru/article/n/eksperimentalnaya-ploschadka-kak-innovatsionnaya-sot sialno-pedagogicheskaya-sistema

2. G.A. Ignatieva, A.S. Molkov, ISOM, 3 (2012). Accessed on: April 25, 2021. [Online]. Available:

http://cyberleninka.ru/article/n/innovatsionnaya-ploschadka-kak-mesto-vstrechi-praktik oorientirovannoy-nauki-i-naukoorientirovannoy-praktiki

3. I.G. Mineralova, Children's Literature and Strategies of Modern Education, in The European Proceedings of Social \& Behavioural Sciences (EpSBS), IFTE 2016 - 2nd International Forum on Teacher Education, 19-21 May 2016, Kazan Federal University, Russia, XII, 134-138 (2016). Accessed on: April 27, 2021. [Online]. Available: http://www.futureacademy.org.uk/publication/EpSBS/IFTE2016VolumeXII

4. N.V. Zenkina, Bulletin of the FESSL, 2(47), 136-139 (2000)

5. V.A. Golobokova, M.V. Zinovieva, Family reading as an important component of spiritual and moral education, in N.Y. Bezborodova, N.V. Styuflyaeva (eds.), Materials of the "Zadonsk St. Tikhon Educational Readings" XIII International Forum, 171-173 (Semenov-Tyan-Shanskiy Lipetsk State Pedagogical University, Lipetsk, 2018)

6. L.I. Palikova, Inform-education, 1, 188-192 (2016)

7. N. Nikolayeva, N. Mikhaylov, S. Semenova, E. Mikhaylova, Yelena Derevleva, Professional standards for training of teachers to ensure the quality of education in a city, in SHS Web of Conferences, 98, 03014 (2021). Accessed on: April 27, 2021. [Online]. Available: 
https://www.shsconferences.org/articles/shsconf/abs/2021/09/shsconf_ec2020_03014/s hsconf_ec2020_03014.html

8. O.N. Chelyukanova, Working with Literary Text Outside the Classroom the Role of Multi-Aspect Synthesis in Personality Development, in The European Proceedings of Social \& Behavioural Sciences (EpSBS), IFTE 2016 - 2nd International Forum on Teacher Education, 19-21 May 2016, Kazan Federal University, Russia, XII, 270-276 (2016). Accessed on: April 27, 2021. [Online]. Available: http://www.futureacademy.org.uk/publication/EpSBS/IFTE2016VolumeXII

9. E. Asonova, L. Borusyak, E. Romanicheva, K. Kikteva, Education in the library: luxury or a citizen's guaranteed quality of life, in SHS Web of Conferences, 98, 03004 (2021). Accessed on: April 27, 2021. [Online]. Available:

https://www.shsconferences.org/articles/shsconf/abs/2021/09/shsconf_ec2020_03004/s hsconf_ec2020_03004.html

10. O. N. A. Chelyukanova, Fantastic and fabulous things in a story for children, in Y.A. Kurdin (ed.), Karpov readings: works of participants of the "Problems of regional folklore and regional studies through history" IX All-Russian scientific-practical conference (Karpov readings), N. Novgorod, Arzamas branch of the SUNN, 250-256 (Arzamas branch of the UNN, Arzamas, 2020)

11. I.T. Gugkaeva, Siberian Pedagogical Journal, 2 (2013). Accessed on: April 26, 2021. [Online]. Available:

https://cyberleninka.ru/article/n/metod-proektov-kak-pedagogicheskaya-tehnologiya

12. N.V. Kostromina, Siberian Pedagogical Journal, 12 (2007). Accessed on: April 26, 2021. [Online]. Available:

https://cyberleninka.ru/article/n/pedagogicheskie-tehnologii-obucheniya-suschnost-ih-h arakteristiki-i-effektivnost

13. L.G. Svetonosova, Models, systems, networks in economics, technology, nature, and society, 3(4) (2012). Accessed on: April 27, 2021. [Online]. Available: https://cyberleninka.ru/article/n/strukturno-funktsionalnaya-harakteristika-klyuchevyhkompetentsiy-studentov-pedagogicheskogo-vuza 